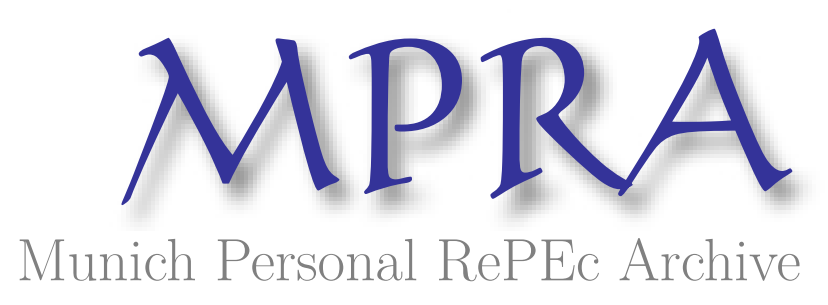

\title{
Temporal Causality and the Dynamics of Crime in Turkey
}

Halicioglu, Ferda

Department of Economics, Yeditepe University

2012

Online at https://mpra.ub.uni-muenchen.de/41794/

MPRA Paper No. 41794, posted 07 Oct 2012 15:15 UTC 


\title{
Temporal Causality and the Dynamics of Crime in Turkey
}

\begin{abstract}
This study is concerned with understanding of the factors of aggregate, nonviolent and violent crime categories in Turkey for the period 1965-2009. The determinants of all crime categories are related to selected socio-economic factors. Bounds testing approach to cointegration is employed to test the existence of long-run relationship amongst the variables. Cointegration analysis yields the major contributors of crime are income and unemployment. The direction of causalities between the variables are established using within and out of sample causality tests. The findings from this study present the dynamics of aggregate, violent and non-violent crimes to design and implement any relevant policy measures to combat them.
\end{abstract}

Keywords: crime, cointegration, causality, time series, Turkey

JEL Classifications: C22, A14, K42

\section{Correspondence to:}

\section{Ferda HALICIOGLU}

Department of Economics, Yeditepe University, Istanbul, 34755

Turkey

fhalicioglu@yeditepe.edu.tr 


\section{Introduction}

The theoretical and empirical work on the socio-economic determinants of crime has grown substantially since the seminal study of Becker (1968), which suggests that the criminal behaves in a rational way and decides how to allocate time between legitimate and illegitimate activities, based on an income benefit-cost comparison, plus the likelihood of apprehension and conviction.

Crime is a universal problem which has a detrimental effect on the functioning and stability of society. Moreover, prevention of crime is always a major public policy concern for all countries due to its socio-economic implications and costs. The extent of crimes may vary from country to country. However, a recent study of Harrendorf et al. (2010) provides some comparable international crime statistics based on the police records in homicide, assault, rape, robbery, burglary, motor vehichle theft and kidnapping rates for 144 countries. All crime rates are reported below per 100,000 population. As of 2004, approximately 490,000 deaths from international homicide occured revealing the rate of 7.6. In the same year, there were 4973 Turkish homicides, which produced the homicide rate of 7.07. As of 2006, the mean assault rate in the world was 251 whilst it was 192.7 in Turkey. Considering rape rates, the mean world rape rate was 12 but Turkey had a substantially low rape rate value of 2.5. Even though Harrendorf et al. (2010) reports individually the mean robbery rates for 144 countries but the mean value was not presented. The robbery rate for Turkey was revealed as 28.3 which was classified as low. The mean burglary rate for the world was illustrated as 339 whereas Turkey had a burglary rate of 216.9. As for the mean motor vehicle theft rates, Turkish rate, 45.9 is well below of the world average of 118 . Finally, the kidnapping rates were compared, according to this rate, Turkey ranked the top with a rate of 14.84 whereas the mean world kidnapping was only 1.7 . 
The international crime statistics demonstrate that the crime rates in Turkey apart from the kidnapping rates are below the world averages indicating low occurance of criminal activities. The crime rates in Turkey, nevertheless, seem to be on surge considering the data provided by Turkish Institute of Statistics (TSI), as of January 2011, there were 66997 convicts in the Turkish prisons which convert as 91.52 conviction per 100,000 population and the Turkish prisons are overflowed by the number of convicts and the people arrested waiting for trials, currently 55407. However, it should be noted that an increase in conviction rate may not be directly imply a rise in crime activities as the extent and definitions of crime categories may be modified considerably regarding the crime time series data.

An empirical study of crime in Turkey may provide useful policy tools for the policy makers to predict the future development on aggregate, violent and nonviolent crimes. The development in crime is a crucial factor in demands which are placed on the police and the criminal justice system. The empirical studies aiming at determining the causes of crime in Turkey are limited. For example, Kustepeli and Onel (2006) applies Johansen-Juselius (1990) cointegration approach to identify the determinants of crime using annual data of 1967-2004 but it is well documented the adopted cointegration methodology is strictly for large samples. Therefore, the results from Kustepeli and Onel (2006) are considered as flawed. The study of Comertler and Kar (2007) on crime is based on cross-section data, as a result it lacks of direction of causations between the variables. As far as this study is concerned, there exists no previous study that estimates empirically the determinants of crime in Turkey implementing the cointegration framework of Pesaran et al. (2001). Thus, this study aims at contributing to the existing literature by providing fresh evidence on the determinants of crime in addition to causality tests within and out of sample. 
It is expected that the results from this study will have also some implications for the countries which are in the same development stage of Turkey. The extensions and modifications of the model presented here may also contribute to the enrichment of the existing literature on quantitative crime studies.

The remainder of this paper is organized as follows. Section 2 presents a brief literature review. Section 3 describes the study's model and methodology. Section 4 discusses the empirical results, and finally Section 5 concludes.

\section{A brief literature review}

Ehrlich (1973) further extended the research of Becker (1968) on crime and introduced initial econometrics model of offences. Ehrlich (1996) outlines the main themes of the literature on crime. The existing literature in crime economics divides the variables affecting the crime rate broadly into three categories: economic, socioeconomic-demographic, and deterrent.

There are two most frequently used economic variables that are linked to criminal activities, unemployment and income. Cantor and Land (1985) proposed that there are two distinct and potentially counter balancing mechanisms which unemployment may affect crime rates in the aggregate: motivation and criminal opportunity. Former approach relates unemployment to crime rates positively in which a rise in unemployment leads to economic problems and increases the motivation to engage in criminal acts, see for example Reilly and Witt (1992) and Edmark (2005). Latter approach sets up an inverse relationship between these two variables indicating that economic deprivation leads reduction in the supply of worthwhile targets for the criminals. A variant of the latter approach also suggests that a rise in unemployment rates leads to decrease in median family income and discourages a person from the decision to commit a crime as discussed in Britt (1994) and Melick (2004). The link 
between income and crime is formed through three different ways. First an income decrease causes the need for returns from illegal activities; see for example Machin and Meghir (2000). Second an income increase sets the opportunities for criminal activities due to the large amount of stolen goods as pointed out in Lewitt (1999). Third a rise in income leads to outdoor activities, which stimulates potential crime activities, as discussed in Beki et al. (1999). This impact may occur in reverse order if a rise in income leads to a decrease in unemployment which alleviates the need for crime. As for the socioeconomic-demographic determinants of crime, urbanization appears to be one of key explanatory factor with an implication that it causes an increase in criminal activities, see for example Masih and Masih (1996). According to Gartner (1990), the rate of divorce is related to criminal activities as such that changing guardianship and the members of disturbed families pose risk everyone in the society. The impact of deterrent variables such as the number of police force or security expenditures, conviction rates, arrests on crime appear to be usually positive apart from some crime categories since they do not always lead to conviction or arrest, see for example Corman et al. (1987).

There is a very large and growing body of research on different categories of crime linking them with a number of socio-economic determinants. Soares (2004) provides an extensive survey of the empirical studies on crime rates based on 40 studies. An earlier survey of Chiricos (1987) especially presents detailed evidence on the relationship between crime and unemployment rates from 63 research articles.

Table 1 reveals that the empirical studies on crime is based on a number of different empirical methods ranging from simple correlation to sophisticated panel econometric procedures with different categories of crime applying cross section to time series data. The selection of the explanatory variables largely depends on the availability of data and choice of 
researchers indicating the diversity of the empirical evidence on crime. The recent studies usually tend to apply cointegration framework and time series data.

Table 1. Summary results of the selected empirical works on crime

\begin{tabular}{llllll}
\hline Author(s)/Year & Crime Category & Period & Data & Method & Country \\
\hline Beki et al . (1999) & AC & $1950-1993$ & TS & EG & The Netherlands \\
Bodmand and Maulty (1997) & DC & $1982-1991$ & PTS & OLS & Australia \\
Brown (2001) & AC & 1995 & CS & PBC & South Africa \\
Comertler and Kar (2007) & DC & 2000 & CS & OLS & Turkey \\
Canton and Land (1985) & DC & $1946-1982$ & TS & OLS & USA \\
Corman et al. (1987) & DC & $1970-1984$ & TS & VAR & USA \\
Detotto and Pulina (2009) & DC & $1970-2004$ & TS & ARDL & Italy \\
Edmark (2005) & AC and DC & $1988-1999$ & Panel & PEM & Sweden \\
Funk and Kugler (2003) & DC & $1984-1998$ & TS & VAR & Switzerland \\
Habibullah and Baharom (2009) & DC & $1973-2003$ & TS & ARDL & Malaysia \\
Hale (1998) & DC & $1946-1991$ & TS & VECM & UK \\
Kustepeli and Onel (2006) & DC & $1967-2004$ & TS & VECM & Turkey \\
Lee and Holoviak (2006) & AC and DC & various & TS & VECM & 5 Countries \\
Luiz (2000) & DC & $1960-1993$ & TS & VECM & South Africa \\
Machin and Meghir (2004) & AC & $1975-1996$ & TS & OLS/IV & UK \\
Masih and Masih (1996) & DC & $1963-1990$ & TS & VECM & Australia \\
Meera and Jayakumar (1995) & DC & $1968-1988$ & TS & TSLS & Malaysia \\
Nikolaos and Alexandros (2009) & AC & $1971-2006$ & TS & VECM & Greece \\
Narayan and Smyth (2004) & DC & $1964-2001$ & TS & ARDL & Australia \\
Saridakis (2004) & AC and DC & $1960-2000$ & TS & VECM & USA \\
Scorcu and Cellini (1998) & DC & $1951-1994$ & TS & ECM & Italy \\
Shoesmith (2010) & DC & $1970-2003$ & TS & VECM & USA \\
Reilly and Witt (1992) & DC & $1974-1988$ & TS & OLS & Scotland \\
\hline
\end{tabular}

Keys: AC (Aggregate Crime), DC (Disaggregate Crime), EG (Engle-Granger), CS (Cross-Section), TS (Time Series), PTS (Pooled Time Series), Likelihood), OLS (Ordinary Least Squares), PBC (Pearson Pairwise Correlation), IV (Instrumental Variables), TSLS (Two Stage Least Squares), ECM (Error Correction Model), PEM (Panel Econometric Methods), VAR (Vector Auto Regression), ARDL (Auto Regressive Distributed Lag), VECM (Vector Error Correction Model).

\section{Model and methodology}

Following the empirical literature on crime, this study adopts the following long-run relationship between crime, income, unemploymet, divorce, urbanization and security expenditures in double linear logarithmic form as:

$$
c_{t j}=a_{0}+a_{1} y_{t}+a_{2} u_{t}+a_{3} d_{t}+a_{4} r+a_{5} s_{t}+\varepsilon_{t},
$$


where the subscript $t$ indexes time period with $t=1965, \ldots, 2009 ; c_{t}$ is convicts per 100,000 people; $j$ indexes convict variable with $j=0$ (aggregate crime is the combination of nonviolent and violent offences), 1 (nonviolent crime consist of property, burglary, motor vehicle theft, fraud, corruption, etc.), and 2 (violent crime includes homicide, assault, rape, and kidnapping); $y_{t}$ is real income per capita; $u_{t}$ is unemployment rate; $d_{t}$ is divorce rate per $1000 ; r_{t}$ is urbanization rate; $s_{t}$ is real public security expenditures per capita; and $\varepsilon_{t}$ is the classical error term.

\section{Cointegration}

Recent advances in econometric literature dictate that the long-run relation in equation (1) should incorporate the short-run dynamic adjustment process. It is possible to achieve this aim by expressing equation (1) in an error-correction model as suggested in Pesaran et al. (2001).

$$
\begin{aligned}
& \Delta c_{t, j}=\beta_{0}+\sum_{i=1}^{n 1} \beta_{1 i, j} \Delta c_{t-i, j}+\sum_{i=0}^{n 2} \beta_{2 i} \Delta y_{t-i}+\sum_{i=0}^{n 3} \beta_{3 i} \Delta u_{t-i}+\sum_{i=0}^{n 4} \beta_{4 i} \Delta d_{t-i}+\sum_{i=0}^{n 5} \beta_{5 i} \Delta r_{t-i}+\sum_{i=0}^{n 6} \beta_{6 i} \Delta s_{t-i} \\
& +\beta_{7} c_{t-1, j}+\beta_{8} y_{t-1}+\beta_{9} u_{t-1, j}+\beta_{10} d_{t-1}+\beta_{11} r_{t-1}+\beta_{12} s_{t-1}+v_{t}
\end{aligned}
$$

This approach, also known as autoregressive-distributed lag (ARDL), provides the short-run and long-run estimates simultaneously. Short-run effects are reflected by the estimates of the coefficients attached to all first-differenced variables. The long-run effects of the explanatory variables on the dependent variable are obtained by the estimates of $\beta_{8}-\beta_{12}$ that are normalized on $\beta_{7}$. The inclusion of the lagged-level variables in equation (2) is verified through the bounds testing procedure, which is based on the Fisher (F) or Wald (W)-statistics. This procedure is considered as the pre-testing stage of the ARDL cointegration method. Accordingly, a joint significance test that implies no cointegration hypothesis, $\left(\mathrm{H}_{0}\right.$ : all $\beta_{7}$ to 
$\left.\beta_{12}=0\right)$, against the alternative hypothesis, $\left(\mathrm{H}_{1}\right.$ : at least one of $\beta_{7}$ to $\left.\beta_{12} \neq 0\right)$ should be performed for equation (2). The $\mathrm{F} / \mathrm{W}$ test used for this procedure has a non-standard distribution. Thus, Pesaran et al. (2001) compute two sets of critical values for a given significance level with and without a time trend. One set assumes that all variables are $I(0)$ and the other set assumes they are all I(1). If the computed F/W-statistic exceeds the upper critical bounds value, then the $\mathrm{H}_{0}$ is rejected, implying cointegration. In order to determine whether the adjustment of variables is toward their long-run equilibrium values, estimates of $\beta_{7}-\beta_{12}$ are used to construct an error-correction term (EC). Then lagged-level variables in equation (2) are replaced by $\mathrm{EC}_{\mathrm{t}-1}$ forming a modified version of equation (2) as follows:

$$
\begin{aligned}
& \Delta c_{t . j}=\alpha_{0}+\sum_{i=1}^{n 1} \alpha_{1 i, j} \Delta c_{t-i, j}+\sum_{i=0}^{n 2} \alpha_{2 i} \Delta y_{t-i}+\sum_{i=0}^{n 3} \alpha_{3 i} \Delta u_{t-i}+\sum_{i=0}^{n 4} \alpha_{4 i} \Delta d_{t-i}+ \\
& \sum_{i=0}^{n 5} \alpha_{5 i} \Delta r_{t-i}+\sum_{i=0}^{n 6} \alpha_{6 i} \Delta s_{t-i}+\lambda E C_{t-1}+\mu_{t}
\end{aligned}
$$

Equation (3) is re-estimated one more time using the same lags previously. A negative and statistically significant estimation of $\lambda$ not only represents the speed of adjustment but also provides an alternative means of supporting cointegration between the variables. Pesaran et al. (2001) cointegration approach has some methodological advantages in comparison to other single cointegration procedures. Reasons for the ARDL are: i) endogeneity problems and inability to test hypotheses on the estimated coefficients in the long-run associated with the Engle-Granger (1987) method are avoided; ii) the long and short-run coefficients of the model in question are estimated simultaneously; iii) the ARDL approach to testing for the existence of a long-run relationship between the variables in levels is applicable irrespective of whether the underlying regressors are purely stationary $I(0)$, purely non-stationary $I(1)$, or mutually 
cointegrated; iv) the small sample properties of the bounds testing approach are far superior to that of multivariate cointegration, as argued in Narayan (2005).

\section{Augmented Granger Causality}

The Granger representation theorem suggests that there will be Granger causality in at least one direction if there exists a cointegration relationship among the variables in equation (1), providing that they are integrated order of one. Engle and Granger (1987) caution that the Granger causality test, which is conducted in the first-differenced variables by means of a VAR, will be misleading in the presence of cointegration. Therefore, an inclusion of an additional variable to the VAR system, such as the error correction term would help us to capture the long-run relationship. To this end, an augmented form of the Granger causality test involving the error correction term is formulated in a multivariate $p$ th order vector error correction model.

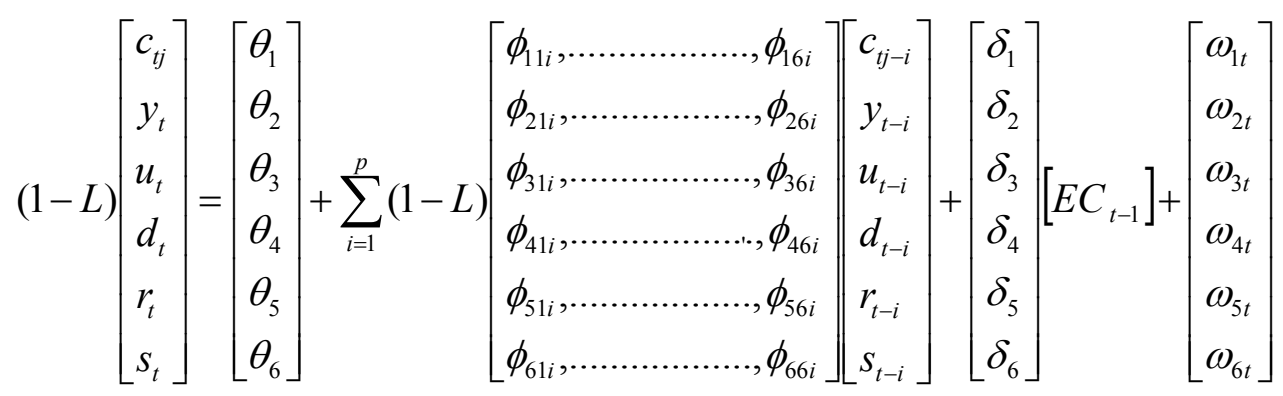

$(1-L)$ is the lag operator. $\mathrm{EC}_{\mathrm{t}-1}$ is the error correction term, which is obtained from the longrun relationship described in equation (1), and it is not included in equation (4) if one finds no cointegration amongst the vector in question. The Granger causality test may be applied to equation (4) as follows: i) by checking statistical significance of the lagged differences of the variables for each vector; this is a measure of short-run causality; and ii) by examining 
statistical significance of the error-correction term for the vector that there exists a long-run relationship. As a passing note, one should reveal that equation (3) and (4) do not represent competing error-correction models because equation (3) may result in different lag structures on each regressors at the actual estimation stage; see Pesaran et al. (2001) for details and its mathematical derivation. All error-correction vectors in equation (4) are estimated with the same lag structure that is determined in unrestricted VAR framework.

\section{Variance Decompositions}

Establishing Granger causality is restricted to essentially within sample tests, which are useful in distinguishing the plausible Granger exogeneity or endogenity of the dependent variable in the sample period, but are unable to deduce the degree of exogenity of the variables the beyond the sample period. To examine this issue, the decomposition of variance of the variables may be used. The variance decompositions (VDCs) measure the percentage of a variable's forecast error variance that occurs as the result of a shock (or an innovation) from a variable in the system. The VDCs estimate the percentage contribution of each variable including the dependent variable in the total variation of the dependent variable. Sims (1980) notes that if a variable is truly exogenous with respect to the other variables in the system, own innovations will explain all of its forecast error variance (i.e., almost 100\%). By looking at VDCs policy makers gather additional insight as to what percentage (of the forecast error variance) of each variable is explained by its determinant.

\section{Results}


Annual data over the period 1965-2009 were used to estimate equation (2) and (3) by the ARDL cointegration procedure of Pesaran et al. (2001). Variable definition and sources of data are cited in Appendix.

To implement the Pesaran et al. (2001) procedure, one has to ensure that none of the explanatory variables in equation (1) is above $I(1)$. In the presence of $I(2)$, the critical values computed by the Pesaran et al. (2001) cointegration procedure are not valid. Three tests were used to test unit roots in the variables: Augmented Dickey-Fuller (henceforth, ADF) (1979, 1981), Phillips-Perron (henceforth, PP) (1988), and Elliott-Rothenberg-Stock (henceforth, ERS) (1996). Unit root tests results are displayed in Table 2. Table 2 demonstrates that none of the variables included in the model are beyond $I(1)$. Consequently, the results warrant implementing the Pesaran et al. (2001) procedure. Visual inspections of the variables in logarithm show no structural breaks.

Table 2. Unit root results

\begin{tabular}{llll}
\hline Variables & ADF & PP & ERS \\
\hline$c_{t, 0}$ & 2.55 & 2.53 & 1.48 \\
$c_{t, 1}$ & 2.64 & 2.29 & 1.32 \\
$c_{t, 2}$ & 1.77 & 1.56 & 1.36 \\
$y_{t}$ & 0.97 & 0.58 & 1.35 \\
$u_{t}$ & 2.30 & 2.56 & 1.70 \\
$d_{t}$ & 1.46 & 1.23 & 1.04 \\
$r_{t}$ & 1.77 & 0.65 & 1.94 \\
$s_{t}$ & $3.72^{*}$ & $3.48^{*}$ & $2.79^{*}$ \\
$\Delta c_{t, 0}$ & $7.75^{*}$ & $9.32^{*}$ & $5.08^{*}$ \\
$\Delta c_{t, 1}$ & $6.23^{*}$ & $8.02^{*}$ & $4.27^{*}$ \\
$\Delta c_{t, 2}$ & $6.10^{*}$ & $7.50^{*}$ & $4.29^{*}$ \\
$\Delta y_{t}$ & $5.22^{*}$ & $5.50^{*}$ & $5.26^{*}$ \\
$\Delta u_{t}$ & $4.46^{*}$ & $5.51^{*}$ & $4.47^{*}$ \\
$\Delta d_{t}$ & 3.05 & $5.29^{*}$ & $3.77^{*}$ \\
$\Delta r_{t}$ & 3.02 & $4.10^{*}$ & 2.90 \\
$\Delta s_{t}$ & 3.09 & $7.14^{*}$ & 3.24 \\
\hline
\end{tabular}

Notes: Sample levels are 1966-2009 and differences are 19672009. The sample level unit root regressions include a constant and a trend. The differenced level unit root regressions are with a constant and without a trend. All test statistics are expressed in absolute terms for convenience. Rejection of unit root hypothesis is indicated with an asterisk. $\Delta$ stands for first difference. 
In order to test the existence of a long-run cointegrating relationship amongst the variables of equation (1), a two-step procedure to estimate the ARDL representation model was carrried out. First, in search of the optimal lag length of the differenced variables of the short-run coefficients in equation (2), unrestricted Vector Auto Regression (VAR) was employed by means of Akaike Information criteria (AIC). The results suggest the optimal lag length for all crime models is 2 , but this stage of the results is not presented here to conserve space. Second, a bound $\mathrm{F} / \mathrm{W}$-test was applied to equation (2) in order to determine whether the dependent and independent variables are cointegrated in each crime model. The results of the bounds F/Wtesting are reported in Table 3. It can bee seen from Table 3 that the computed F/W statistics are above the upper bound values in all cases of crime models thus implying cointegration relations.

Table 3. The results of $\mathrm{F}$ and $\mathrm{W}$ tests for cointegration.

Panel A: The assumed long-run relationship: $F / W\left(c_{0} \mid y, u, d, r, s\right)$

\begin{tabular}{|c|c|c|c|c|}
\hline F-statistic & $95 \% \mathrm{LB}$ & $95 \% \mathrm{UB}$ & $90 \% \mathrm{LB}$ & $90 \% \mathrm{UB}$ \\
\hline 4.15 & 3.00 & 4.25 & 2.48 & 3.65 \\
\hline W-statistic & & & & \\
\hline 24.92 & 18.04 & 25.51 & 14.89 & 21.91 \\
\hline \multicolumn{5}{|c|}{ Panel B: The assumed long-run relationship: $F / W\left(c_{1} \mid y, u, d, r, s\right)$} \\
\hline F-statistic & $95 \% \mathrm{LB}$ & $95 \% \mathrm{UB}$ & $90 \% \mathrm{LB}$ & $90 \% \mathrm{UB}$ \\
\hline 4.94 & 3.00 & 4.25 & 2.48 & 3.65 \\
\hline \multicolumn{5}{|l|}{ W-statistic } \\
\hline 29.64 & 18.04 & 25.51 & 14.89 & 21.91 \\
\hline
\end{tabular}

Panel C: The assumed long-run relationship: $F / W\left(c_{2} \mid y, u, d, r, s\right)$

\begin{tabular}{lllll}
\hline F-statistic & $95 \%$ LB & $95 \%$ UB & $90 \%$ LB & $90 \%$ UB
\end{tabular}

$\begin{array}{lllll}4.51 & 3.00 & 4.25 & 2.48 & 3.65\end{array}$

W-statistic

$\begin{array}{lllll}27.07 & 18.04 & 25.51 & 14.89 & 21.91\end{array}$

If the test statistic lies between the bounds, the test is inconclusive. If it is above the upper bound (UB), the null hypothesis of no level effect is rejected. If it is the below the lower bound (LB), the null hypothesis of no level effect cannot be rejected.

The ARDL representation equation was estimated to obtain the long-run and short-run coefficients simultaneously. The results are displayed in Tables 4, 5 and 6, respectively. The long-run results received from equation (2) are displayed in Panel A of Tables 4, 5 and 6, 
respectively. The error-correction representations from the estimations of equation (3) are presented in Panel B of Tables 4, 5 and 6, respectively. The stability of coefficients in the error correction models were also checked via the graphical representations of CUSUM and CUSUMSQ tests of Brown et al. (1975). The results display that all coefficients in the errorcorrection models are stable and there exist no structural breaks. These results are not illustrated here due space considerations.The overall regression diagnostics in all models suggest that the econometric results are satisfactory to infer from them.. Regarding the aggregate crime model, in the long-run all the parameters seem to be carrying expected signs but three of them: income, unemployment and divorce rates are statistically and individually significant. Amongst these variables, income variable has the highest partial impact on crime indicating that a $1 \%$ increase in real per capita income decreases aggregate crime by $1.60 \%$ in the long-run. The elasticity of aggregate crime with respect to unemployment rate is -0.53 implying that a $1 \%$ rise in the unemployment rate will reduce the criminal opportunities by $0.53 \%$. The impact of unemployment on crime is frequently tested as it is considered as one of major determinants of crime offenses. Chiricos (1987) for extensive survey linking the unemployment and crime rates. As for the divorce variable, its affect on the aggregate crime level is rather noticeable since a $1 \%$ increase in divorce rates leads to $0.36 \%$ in the aggregate crime. The short-run estimation of the aggregate crime model reveals that the estimated error correction term is very high $(-0.85)$ therefore any disequlibrium between the short-run and long-run is eliminated within a short-period of time. In other words, the aggregate crime equation is above or below its equilibrium level, it adjusts by $85 \%$ within the first year. The full convergence to its equilibrium level takes a little less than one and a half years. 
Table 4. Aggregate Crime Model ARDL cointegration results

\begin{tabular}{|c|c|c|c|c|c|}
\hline \multicolumn{3}{|c|}{$\begin{array}{l}\text { Panel A. } \\
\text { Long-run results. }\end{array}$} & \multicolumn{3}{|c|}{$\begin{array}{l}\text { Panel B. } \\
\text { Error correction representation results. }\end{array}$} \\
\hline \multicolumn{3}{|c|}{ Dependent variable $c_{t, 0}$} & \multicolumn{3}{|c|}{ Dependent variable $\Delta c_{t, 0}$} \\
\hline Regressor & Coefficient & T-ratio & Regressor & Coefficient & T-ratio \\
\hline$y_{t}$ & $-1.6068^{*}$ & 6.1620 & $\Delta y_{t}$ & $-0.9805^{*}$ & 4.3911 \\
\hline$u_{t}$ & $-0.5291^{*}$ & 2.8864 & $\Delta u_{t}$ & $-0.3181^{*}$ & 2.9173 \\
\hline$d_{t}$ & $0.3620^{*}$ & 3.7559 & $\Delta d_{t}$ & $0.2913^{*}$ & 3.2662 \\
\hline$r_{t}$ & 0.6479 & 1.1785 & $\Delta r_{t}$ & $0.5670^{*}$ & 2.5141 \\
\hline$S_{t}$ & -0.1423 & 0.7820 & $\Delta s_{t}$ & 0.4834 & 1.5775 \\
\hline Constant & $23.099^{*}$ & 10.618 & $E C_{t-1}$ & $-0.8570^{*}$ & 4.3542 \\
\hline
\end{tabular}

Panel C.

Diagnostic tests.

\begin{tabular}{llllllll}
\hline $\bar{R}^{2}$ & 0.54 & F-statistic & $7.58^{*}$ & $\chi_{S C}^{2}(1)$ & 0.24 & $\chi_{F F}^{2}(1)$ & 0.11 \\
RSS & 0.95 & DW-statistic & 2.19 & $\chi_{N}^{2}(2)$ & 3.39 & $\chi_{H}^{2}(1)$ & 0.47 \\
\hline
\end{tabular}

${ }^{*},{ }^{* *}$, and, ${ }^{* * *}$ indicate, $1 \%, 5 \%$, and $10 \%$ significance levels respectively. RSS stands for residual sum of squares. Tratios are in absolute values. $\chi_{S C}^{2}, \chi_{F F}^{2}, \chi_{N}^{2}$, and $\chi_{H}^{2}$ are Lagrange multiplier statistics for tests of residual correlation, functional form mis-specification, non-normal errors and heteroskedasticity, respectively. These statistics are distributed as Chi-squared variates with degrees of freedom in parentheses. The critical values for $\chi^{2}(1)=3.84$ and $\chi^{2}(2)=5.99$ are at $5 \%$ significance level.

The nonviolent crime model is displayed in Table 5 indicating that income, unemployment and divorce rate variables are also here statistically and individually significant in the longrun. In fact, the order of their impacts on the dependent variables follow the same order as in the case of the pervious model but the magnitudes are different. For example, the elasticity of the nonviolent crime with respect to income is almost -1 impying that there is an exact proportional change between these variables but it is substantially less in comparison to the aggregate crime results. The partial impact of unemployment on the nonviolent crime is here much higher than the previous category of crime. Similarly, the elasticity of the nonviolent crime is almost twice more than the aggregate crime model. Nevertheless, the error correction term seems to be quite close in both crime models. 
Table 5. Nonviolent Crime Model ARDL cointegration results

\begin{tabular}{lcclll}
\hline \multicolumn{2}{l}{$\begin{array}{l}\text { Panel A. } \\
\text { Long-run results. }\end{array}$} & \multicolumn{5}{l}{$\begin{array}{l}\text { Panel B. } \\
\text { Error correction representation results. }\end{array}$} \\
\hline \multicolumn{2}{l}{$\begin{array}{l}\text { Dependent variable } c_{t, 1} \\
\text { Regressor }\end{array}$} & Coefficient & T-ratio & \multicolumn{4}{l}{$\begin{array}{l}\text { Dependent variable } \\
\text { Regressor }\end{array}$} & Coefficient & T-ratio \\
\hline$y_{t}$ & $-0.9931^{*}$ & 2.9345 & $\Delta y_{t}$ & $-0.9276^{* *}$ & 2.3731 \\
$u_{t}$ & $-0.8096^{*}$ & 3.9908 & $\Delta u_{t}$ & $-0.7562^{*}$ & 3.8019 \\
$d_{t}$ & $0.6721^{*}$ & 5.6743 & $\Delta d_{t}$ & 0.1055 & 0.3934 \\
$r_{t}$ & 0.2563 & 0.5015 & $\Delta r_{t}$ & 0.2394 & 0.4943 \\
$s_{t}$ & 0.0361 & 0.2554 & $\Delta s_{t}$ & $0.0126^{* *}$ & 2.2311 \\
Constant & $18.133^{*}$ & 7.9132 & $E C_{t-1}$ & $-0.9340^{*}$ & 6.3036 \\
\hline
\end{tabular}

Panel C.

Diagnostic tests.

\begin{tabular}{llllllll}
\hline $\bar{R}^{2}$ & 0.52 & F-statistic & $7.11^{*}$ & $\chi_{S C}^{2}(1)$ & 2.39 & $\chi_{F F}^{2}(1)$ & 2.66 \\
RSS & 0.65 & DW-statistic & 2.27 & $\chi_{N}^{2}(2)$ & 5.19 & $\chi_{H}^{2}(1)$ & 1.28 \\
\hline
\end{tabular}

${ }^{*},{ }^{* *}$, and, ${ }^{* * *}$ indicate, $1 \%, 5 \%$, and $10 \%$ significance levels respectively. RSS stands for residual sum of squares. Tratios are in absolute values. $\chi_{S C}^{2}, \chi_{F F}^{2}, \chi_{N}^{2}$, and $\chi_{H}^{2}$ are Lagrange multiplier statistics for tests of residual correlation, functional form mis-specification, non-normal errors and heteroskedasticity, respectively. These statistics are distributed as Chi-squared variates with degrees of freedom in parentheses. The critical values for $\chi^{2}(1)=3.84$ and $\chi^{2}(2)=5.99$ are at $5 \%$ significance level.

Considering the last category of crime model, even though income and divorce rate variables are statitically and individually significant as in the case of both previous models. However, the unemployment variable is not statistically significant in this crime model. Instead, urbanization variable appears to be statitically significant. The magnitude of the partial impact of income on the violent crime level is the almost same as the non-violent crime in the longrun. The elasticity of violent crime with respect to divorce rate is considerably less than the nonviolent crime category but substantially higher than the aggregate crime model. It seems that urbanization is only statistically significant in the case of this category crime. Its estimated coefficent indicates that a $1 \%$ rise in the urbanization rate reduces the violent crime by $1.42 \%$. As people live close by it is likely that crime rates will drop in comparison to sparsely located residents. As for the error correction term, its magnitute between the aggregate and nonviolent crime models. 
Table 6. Violent Crime Model ARDL cointegration results

\begin{tabular}{llllll}
\hline \multicolumn{2}{l}{$\begin{array}{l}\text { Panel A. } \\
\text { Long-run results. }\end{array}$} & \multicolumn{5}{l}{$\begin{array}{l}\text { Panel B. } \\
\text { Error correction representation results. }\end{array}$} \\
\hline \multicolumn{2}{l}{$\begin{array}{l}\text { Dependent variable } c_{t, 2} \\
\text { Regressor }\end{array}$} & Coefficient & T-ratio & \multicolumn{4}{l}{$\begin{array}{l}\text { Dependent variable } \\
\text { Regressor }\end{array}$} & Coefficient & T-ratio \\
\hline$y_{t}$ & $-1.0522^{*}$ & 3.0300 & $\Delta y_{t}$ & $-0.9584^{* *}$ & 2.3731 \\
$u_{t}$ & -0.0433 & 0.2090 & $\Delta u_{t}$ & $-0.0337^{* * *}$ & 1.8458 \\
$d_{t}$ & $0.5484^{*}$ & 4.7717 & $\Delta d_{t}$ & 0.1960 & 0.7411 \\
$r_{t}$ & $-1.4247^{* *}$ & 2.6725 & $\Delta r_{t}$ & $-1.2976^{* *}$ & 2.4544 \\
$s_{t}$ & -0.0406 & 0.3058 & $\Delta s_{t}$ & $0.0224^{* * *}$ & 1.7908 \\
Constant & $19.577^{*}$ & 8.2566 & $E C_{t-1}$ & $-0.9108^{*}$ & 5.7330 \\
\hline
\end{tabular}

Panel C.

Diagnostic tests.

\begin{tabular}{|c|c|c|c|c|c|c|c|}
\hline $\bar{R}^{2}$ & 0.40 & F-statistic & $4.95^{*}$ & $\chi_{S C}^{2}(1)$ & 0.10 & $\chi_{F F}^{2}(1)$ & 1.22 \\
\hline RSS & 0.63 & DW-statistic & 1.97 & $\chi_{N}^{2}(2)$ & 0.43 & $\chi_{H}^{2}(1)$ & 0.31 \\
\hline
\end{tabular}

The results of Granger causality tests presented in Tables 7,8 and 9, respectively, reveal the existence of the long-run causality in the case of each crime categories. In the long-run, causality runs from police expenditures, urbanization, divorce, unemployment and income to crimes. Howevever, the short-run causalities differ amongst the models. Regarding the pairs of causalities between only crime and explanatory variables, the following points are identified. There exists a feedback relationship between aggregate crime level and per capita income. The causality running from crime to per capita income suggests that crime is a detrimental factor for the economic growth in the short-run. Similarly, there is also a feedback relationship amongst nonviolent crime and unemployment rate. Finally, it is established that a unilateral causality running from nonviolent crime to divorce rate and violent crime Grangercauses urbanization. 
Table 7. Results of Granger causality for aggregate crime model

\begin{tabular}{|c|c|c|c|c|c|c|c|}
\hline \multicolumn{8}{|c|}{$F$-statistics (probability) } \\
\hline $\begin{array}{l}\text { Dependent } \\
\text { Variable }\end{array}$ & $\Delta c_{t, 0}$ & $\Delta y_{t}$ & $\Delta u_{t}$ & $\Delta d_{t}$ & $\Delta r_{t}$ & $\Delta s_{t}$ & $\begin{array}{l}E C_{t-1} \\
(t \text {-statistic) }\end{array}$ \\
\hline$\Delta c_{t, 0}$ & - & $\begin{array}{l}3.99^{*} \\
(0.01)\end{array}$ & $\begin{array}{l}0.62 \\
(0.60)\end{array}$ & $\begin{array}{l}1.28 \\
(0.30)\end{array}$ & $\begin{array}{l}0.35 \\
(0.78)\end{array}$ & $\begin{array}{l}1.17 \\
(0.33)\end{array}$ & $\begin{array}{l}-0.87^{*} \\
(0.02)\end{array}$ \\
\hline$\Delta y_{t}$ & $\begin{array}{l}3.94^{*} \\
(0.02)\end{array}$ & - & $\begin{array}{l}1.82 \\
(1.16)\end{array}$ & $\begin{array}{l}1.41 \\
(0.26)\end{array}$ & $\begin{array}{l}0.88 \\
(0.46)\end{array}$ & $\begin{array}{l}0.84 \\
(0.48)\end{array}$ & \\
\hline$\Delta u_{t}$ & $\begin{array}{l}0.80 \\
(0.50)\end{array}$ & $\begin{array}{l}0.62 \\
(0.54)\end{array}$ & - & $\begin{array}{l}1.16 \\
(0.34)\end{array}$ & $\begin{array}{l}0.57 \\
(0.63)\end{array}$ & $\begin{array}{l}0.88 \\
(0.46)\end{array}$ & \\
\hline$\Delta d_{t}$ & $\begin{array}{l}0.42 \\
(0.74)\end{array}$ & $\begin{array}{l}1.39 \\
(0.26)\end{array}$ & $\begin{array}{l}0.39 \\
(0.26)\end{array}$ & - & $\begin{array}{l}1.18 \\
(0.33)\end{array}$ & $\begin{array}{l}0.38 \\
(0.76)\end{array}$ & \\
\hline$\Delta r_{t}$ & $\begin{array}{l}0.13 \\
(0.94)\end{array}$ & $\begin{array}{l}2.63^{* *} \\
(0.07)\end{array}$ & $\begin{array}{l}0.46 \\
(0.70)\end{array}$ & $\begin{array}{l}1.29 \\
(0.30)\end{array}$ & - & $\begin{array}{l}0.92 \\
(0.44)\end{array}$ & \\
\hline$\Delta s_{t}$ & $\begin{array}{l}0.70 \\
(0.55)\end{array}$ & $\begin{array}{l}0.84 \\
(0.48)\end{array}$ & $\begin{array}{l}1.27 \\
(0.30)\end{array}$ & $\begin{array}{l}0.46 \\
(0.70)\end{array}$ & $\begin{array}{l}1.47 \\
(0.24)\end{array}$ & - & \\
\hline
\end{tabular}

Causality inference: $c_{t, 0} \leftrightarrow y_{t}, y_{t} \rightarrow r_{t}$

${ }^{*}$ and ${ }^{* *}$ indicate $5 \%$ and $10 \%$ significance levels, respectively. The probability values are in brackets. The optimal lag length is 2 and is based on SBC.

Table 8. Results of Granger causality for nonviolent crime model

\begin{tabular}{llllllll}
\hline \multicolumn{7}{c}{$F$-statistics (probability) } \\
\hline $\begin{array}{l}\text { Dependent } \\
\text { Variable }\end{array}$ & $\Delta c_{t, 1}$ & $\Delta y_{t}$ & $\Delta u_{t}$ & $\Delta d_{t}$ & $\Delta r_{t}$ & $\Delta s_{t}$ & $\begin{array}{l}E C_{t-1} \\
(t \text {-statistic) }\end{array}$ \\
\hline$\Delta c_{t, 1}$ & - & 1.34 & $2.30^{* *}$ & 0.17 & 0.29 & 1.08 & $-0.82^{*}$ \\
& & $(0.28)$ & $(0.10)$ & $(0.91)$ & $(0.82)$ & $(0.37)$ & $(0.00)$ \\
$\Delta y_{t}$ & 1.11 & - & $2.88^{*}$ & 0.48 & 0.62 & 1.39 & \\
& $(0.36)$ & & $(0.05)$ & $(0.69)$ & $(0.60)$ & $(0.27)$ & \\
$\Delta u_{t}$ & $3.48^{*}$ & $2.72^{* *}$ & - & $3.54^{*}$ & 1.14 & 0.52 & \\
& $(0.03)$ & $(0.06)$ & & $(0.03)$ & $(0.35)$ & $(0.66)$ & \\
$\Delta d_{t}$ & $2.33^{* *}$ & $3.36^{*}$ & 1.22 & - & $2.46^{* *}$ & 0.72 & \\
& $(0.10)$ & $(0.03)$ & $(0.32)$ & & $(0.08)$ & $(0.54)$ & \\
$\Delta r_{t}$ & 1.40 & $3.71^{*}$ & 1.16 & $2.39^{* *}$ & - & 1.20 & \\
& $(0.26)$ & $(0.02)$ & $(0.34)$ & $(0.09)$ & & $(0.32)$ & \\
$\Delta s_{t}$ & 1.55 & 1.29 & 0.76 & 0.15 & 2.16 & - & \\
& $(0.22)$ & $(0.29)$ & $(0.52)$ & $(0.92)$ & $(0.11)$ & & \\
\hline
\end{tabular}

Causality inference: $c_{t, 1} \leftrightarrow u_{t}, c_{t, 1} \rightarrow d_{t}, d_{t} \rightarrow u_{t}, y_{t} \leftrightarrow u_{t}, y_{t} \rightarrow d_{t}, r_{t} \leftrightarrow d_{t}, y_{t} \rightarrow r_{t}$ and ${ }^{* *}$ indicate $5 \%$ and $10 \%$ significance levels, respectively. The probability values are in brackets. The optimal lag length is 2 and is based on SBC. 
Table 9. Results of Granger causality for violent crime model

\begin{tabular}{llllllll}
\hline \multicolumn{7}{c}{$F$-statistics (probability) } \\
$\begin{array}{l}\text { Dependent } \\
\text { Variable }\end{array}$ & $\Delta c_{t, 2}$ & $\Delta y_{t}$ & $\Delta u_{t}$ & $\Delta d_{t}$ & $\Delta r_{t}$ & $\Delta s_{t}$ & $\begin{array}{l}E C_{t-1} \\
(t \text {-statistic) }\end{array}$ \\
\hline$\Delta c_{t, 2}$ & - & 0.41 & 1.62 & 0.14 & 0.56 & 0.99 & $-0.97^{*}$ \\
& & $(0.74)$ & $(0.21)$ & $(0.93)$ & $(0.64)$ & $(0.41)$ & $(4.18)$ \\
$\Delta y_{t}$ & 0.69 & - & $2.29^{* *}$ & 0.72 & 0.22 & 0.89 & \\
& $(0.56)$ & & $(0.10)$ & $(0.54)$ & $(0.88)$ & $(0.45)$ & \\
$\Delta u_{t}$ & 1.68 & 1.75 & - & $3.40^{*}$ & 0.61 & 0.55 & \\
& $(0.19)$ & $(0.18)$ & & $(0.03)$ & $(0.60)$ & $(0.65)$ & \\
$\Delta d_{t}$ & 0.93 & 1.96 & 0.59 & - & 1.34 & 0.59 & \\
& $(0.43)$ & $(0.14)$ & $(0.62)$ & & $(0.28)$ & $(0.62)$ & \\
$\Delta r_{t}$ & $2.60^{* *}$ & $3.42^{*}$ & 1.57 & 1.91 & - & 1.82 & \\
& $(0.07)$ & $(0.03)$ & $(0.22)$ & $(0.15)$ & & $(0.17)$ & \\
$\Delta s_{t}$ & 1.06 & 0.81 & 1.18 & 0.26 & $2.47^{* *}$ & - & \\
& $(0.38)$ & $(0.49)$ & $(0.33)$ & $(0.84)$ & $(0.08)$ & & \\
\hline
\end{tabular}

Causality inference: $c_{t, 2} \rightarrow r_{t}, u_{t} \rightarrow y_{t}, d_{t} \rightarrow u_{t}, y_{t} \rightarrow r_{t}, r_{t} \rightarrow s_{t}$
${ }^{*}$ and ${ }^{* *}$ indicate $5 \%$ and $10 \%$ significance levels, respectively. The probability values are in brackets. The optimal lag length is 2 and is based on SBC.

Individually only income and unemployment Granger-caused aggregate nonviolent crime categories in the short-run as indicated by the significance of the F-tests. The short-run disequlibrium in the long-run cointegrating relationships did Granger-caused in all types of crimes since the lagged error term is statiscally significant in all the models. This finding is futher supported by the post-sample VDCs as illustrated in Table 10. A substantial portion of the variance of aggregate crime $(88.26 \%)$ is explained by its own innovations in the shortrun, for example, at two-year horizon. In the long-run, for example, at ten-year horizon, the portion of the variance of aggregate crime gradually decreases to $81.34 \%$ implying that other variables explains about $19 \%$ of the shocks in the aggregate crime. The within-sample VECM results indicate nonviolent crime was Granger-caused by unemployment. The post-sample VDCs further confirms this finding. Adding the relative strenght of income $(8.85 \%)$ and divorce rates $(4.82 \%)$ to this impact, about $45.51 \%$ of the shocks in the nonviolent crime at ten-year horizon are accounted for the shocks in the unemployment, income and divorce rates. VECM estimates analysis suggests that violent crimes were Granger caused partly by growing unemployment rates. This finding is slightly confirmed by VDCs in the long-run too. 
However, a major portion (62.17\%) of the variance in its forecast error at ten-year horizon is accounted for by the summation of five explanatory variables: income $(31.96 \%)$, unemployment $(2.72 \%)$, divorce $(7.03 \%)$, urbanization $(5.39 \%)$, and security expenditures $(15.07 \%)$

Table 10. Decomposition of Variance

\begin{tabular}{|c|c|c|c|c|c|c|}
\hline & \multicolumn{5}{|c|}{ Percentage of forecast variance explained by innovations in: } & \multirow[b]{2}{*}{ Security exp. } \\
\hline & Crime rate & Income & Unemployment & Divorce & Urbanization & \\
\hline Years & & & Aggregate crime & & & \\
\hline 1 & 100.00 & 0.00 & 0.00 & 0.00 & 0.00 & 0.00 \\
\hline 2 & 88.26 & 2.26 & 0.97 & 0.51 & 6.37 & 1.60 \\
\hline 3 & 85.13 & 2.18 & 1.79 & 0.44 & 8.91 & 1.52 \\
\hline 4 & 85.21 & 1.86 & 1.74 & 0.38 & 9.37 & 1.36 \\
\hline 5 & 84.36 & 1.71 & 1.74 & 0.33 & 10.47 & 1.37 \\
\hline \multirow[t]{2}{*}{10} & 81.34 & 1.12 & 1.51 & 0.19 & 14.42 & 1.28 \\
\hline & & & Non-violent crim & & & \\
\hline 1 & 100.00 & 0.00 & 0.00 & 0.00 & 0.00 & 0.00 \\
\hline 2 & 86.67 & 0.13 & 10.25 & 2.92 & 0.01 & 0.01 \\
\hline 3 & 76.98 & 1.73 & 18.80 & 2.81 & 0.01 & 0.16 \\
\hline 4 & 68.32 & 4.41 & 24.07 & 2.99 & 0.01 & 0.16 \\
\hline 5 & 58.80 & 6.50 & 28.60 & 4.07 & 0.01 & 0.15 \\
\hline \multirow[t]{2}{*}{10} & 53.56 & 8.85 & 31.84 & 4.82 & 0.07 & 0.14 \\
\hline & & & Violent crime & & & \\
\hline 1 & 100.00 & 0.00 & 0.00 & 0.00 & 0.00 & 0.00 \\
\hline 2 & 98.44 & 0.84 & 0.01 & 0.21 & 0.39 & 0.01 \\
\hline 3 & 90.41 & 7.96 & 0.38 & 0.58 & 0.44 & 0.20 \\
\hline 4 & 77.59 & 18.12 & 1.10 & 2.26 & 0.36 & 0.54 \\
\hline 5 & 68.21 & 24.79 & 1.89 & 3.80 & 0.51 & 0.78 \\
\hline 10 & 51.37 & 31.96 & 2.72 & 7.03 & 5.39 & 15.07 \\
\hline
\end{tabular}

Notes: Figures in the first column refer to horizons (i.e., number of years). All figures are rounded to two decimal places. The covariances matrices of errors from all the VECMs appeared to be very small and approaching zero suggesting that the combinations of all the variables in these models are linear. Therefore, the ortohogonal case for the variance decompositions are applied.

\section{Conclusions}

This study has attempted to identify the causes of crime in Turkey using the cointegration framework of Pesaran et al. (2001). The results indicate that the existence of cointegration between crime categories, income, unemployment, divorce, urbanization and security expenditures. As a result, although in the short-run, one or two determinants may not be 
related to crime in a temporal causal relationship, in the long-run, it is the dynamic interaction of all these variables with each type of crime is causally related. In regards to long-run partial impacts of explanatory variables on crime categories, income seems to be main factor in determining in all crime rates. This impact highest in total crime category but it is quite similar in the case of violent and non-violent crime. Unemployment is another major factor contributor to all crime rates. However, in the case of violent crime, unemployment is statistically insignificant. Divorce seems to be a positive effect in rising crime and that is particularly high in the case of non-violent crime. It is found that urbanization is contributing to crime if they are in the category of violent offence. Although, the impact of security expenditures appear to have deterring effect on crime but they are statistically not significant. In within sample causality tests suggest that there is a long causality running from police expenditures, urbanization, divorce, unemployment and income to all crimes. In the short-run, a bilateral causality between aggregate crime and income is detected. Similarly, a feedback relationship is established between non-violent crime and income. This finding of a long-run temporal relationship between all these variables is very important for the policy designers to identify causation amongst the variables. Considering out of sample causalities, in the shortrun, all crimes are mainly self-feeding but as time horizon increases the causes of crime are supported by income, unemployment and divorce rates. Security expenditures, however, appears to deterring effect only in the case of violent crime in the long-run. The results from this analysis allow policy designers obtain additional insight as to what percentage of each category of crime is explained by each determinant. As a passing note, it is plausible to suggest that the overall results of this study could have been improved significantly if the conviction rates were replaced by crime index.

The findings from this study present the dynamics of aggregate, violent and non-violent crime to design and implement any relevant policy measures to combat them. With regard to future 
scenarios of economic and development, the estimated model elasticities enable the policy makers to predict the future development on aggregate, violent and non-violent crime. 


\section{Appendix}

\section{Data definition and sources}

Data are collected from three different sources, namely; Statistical Indicators of Turkish Institute of Statistics (TSI), Main Economic Indicators (MEI) of OECD and World Development Indicators (WDI) of World Bank.

$c_{0}, c_{1}, c_{2},:$ are the convicts of total, non-violent and violent crime offences per 100,000 people in logarithm, respectively. Non-violent offences consist of property, burglary, motor vehicle theft, fraud, corruption, etc. Violent crimes include homicide, assault, rape, and kidnapping. Source: TSI.

$y$ : is the per capita real income in Turkish lira based on 2000 prices in logarithm. Source: WDI.

$u:$ is the unemployment rate in logarithm. Source: MEI.

$d:$ is the crude divorce rate per 1000 people in logarithm. Source: TSI.

$r$ : is the urbanization rate in logarithm. The urbanization rate is the proportion of people living in the cities. Source: WDI.

$s:$ is the per capita real public security expenditures in Turkish lira based on 2000 prices in logaritm. The public security expenditures contain police and gendarme forces in the cities and country sides. Source: TSI.

Descriptive statistics of the variables used in the econometric estimations are presented in Table 11.

Table 11. Descriptive Statistics of Variables

\begin{tabular}{lllll}
\hline Variables & Mean & Standard Deviation & Maximum & Minimum \\
\hline$c_{t, 0}$ & 46.83 & 17.20 & 86.86 & 14.75 \\
$c_{t, 1}$ & 18.63 & 6.59 & 33.42 & 9.11 \\
$c_{t, 2}$ & 18.76 & 10.05 & 44.34 & 18.76 \\
$y_{t}$ & 16029.6 & 3673.7 & 21383.7 & 9396.5 \\
$u_{t}$ & 7.97 & 1.88 & 13.05 & 3.06 \\
$r_{t}$ & 0.57 & 0.37 & 1.41 & 0.27 \\
$d_{t}$ & 53.09 & 11.66 & 70.1 & 34.2 \\
$s_{t}$ & 170.87 & 99.93 & 410.61 & 37.59 \\
\hline
\end{tabular}




\section{References}

Becker, G.S. (1968) Crime and punishment: an economic approach, Journal of Political Economy, 76, 169-217.

Beki, C., Zeelenberg, K. and Kees, van M. (1999) An analysis of the crime rate in the Netherlands 1950-1993, British Journal of Criminology, 39, 401-415.

Bodman, P.M. and Maulty, C. (1997) Crime, punishment and deterence in Australia: a further empirical investigation, International Journal of Social Economics, 24, 884-901.

Britt, C. L. (1994) Crime and unemployment among youths in the United States, 1958-1990, American Journal of Economics and Sociology, 53, 99-109

Brown , K.V. (2001) The determinants of crime in South Africa, South African Journal of Economics, 69, 269-298.

Brown, R.L., Durbin, J., Evans, J.M. (1975) Techniques for testing the constancy of regression relations over time, Journal of the Royal Statistical Society, Series B, 37, 149-163.

Cantor, D. and Land, K.C. (1985) Unemployment and crime rates in the Post- Wordl War II United States: a theoretical and empirical analysis, American Sociological Review, 50, 317332.

Chiricos, T.G. (1987) Rates of crime and unemployment: an analysis of aggregate research evidence, Social Problems, 34, 187-212.

Corman, H. Joyce, T., and Lovitch, N. (1987) Crime, deterence and the business cyle in New York, The Review of Economics and Statistics, 69, 695-700.

Comertler, N. and Kar, M. (2007) Economic and social determinants of the crime rate in Turkey: cross-section analysis, The Review of Faculty of Political Sciences of Ankara University, 62, 1-7.

Dickey, D. A. and Fuller, W. A. (1981) Likelihood ratio statistics for autoregressive time series with a unit root, Econometrica, 49, 1057-1072.

Dickey, D. A. and Fuller, W. A. (1979) Distribution of the estimators for autoregressive time series with a unit root, Journal of American Statistician Association, 40, 12-26.

Detotto, C., and Pulina, M. (2009) Does more crime mean fewer jobs? An ARDL model, Working Papers, No.2009/5, Crenos, Cagliari, Italy.

Edmark, K. (2005) Unemployment and crime: is there a connection?, Scandinavian Journal of Economics, 107, 353-373.

Ehrlich, I. (1996) Crime, punishment, and the market for offenses, Journal of Economic Perspectives, 10, 43-67. 
Ehrlich, I. (1973) Participation in illegitimate activities: a theoretical and empirical investigation, Journal of Political Economy, 38, 521-565.

Engle, R. F. and Granger, C. W. J. (1987) Cointegration and error correction: representation, estimation and testing, Econometrica, 55, 251-276.

Elliot, G., Rothenberg, T. and Stock, J. (1996) Efficient tests for an autoregressive unit root, Econometrica, 64, 813-836.

Funk, P., and Kugler, P. (2003) Identifying efficient crime-combating policies by VAR models; the example of Switzerland, Contemporay Economics Policy, 21, 525-538.

Gartner, R. (1990) The victims of homicide: a temporal and cross-national comparisons, American Sociological Review, 55, 92-106.

Hale, C. (1998) Crime and the business cycle in post-Britain revisited, British Journal of Criminology, 38, 681-698.

Harrendorf, S., Heiskanen, M., and Malby, S. (2010) International Statistics on Crime and Justice, United Nations Office on Drugs and Crime, Vienna.

Johansen, S., and Juselius, K. (1990) Maksimum likelihood estimation and inference on cointegration with applications to money demand, Oxford Bulletin of Economics and Statistics, 52,169-210.

Kustepeli, Y., and Onel, G. (2006) Different categories of crimes and their socio-economic determinants in Turkey: evidence from VECM, Conference Paper, presented at Turkish Economic Association on International Conference on Economics, September 11-13, 2006, Ankara.

Lee, D.Y., and Holoviak, S.J. (2006) Unemployment and crime : an empirical investigation, Applied Economics Letters, 13, 805-810.

Luiz, J.M. (2000) Temporal association, the dynamics of crime, and their economic determinants: a time series econometric model of South Africa, Social Indicators Research, 53, 33-61.

Levitt, S. (1999) The changing relationship between income and crime victimization, Federal Reserve Bank of New York Policy Review, 5, 87-98.

Machin, S., and Meghir, C. (2004) Crime and economic incentives, The Journal of Human Resources, 34, 958-970.

Masih, A.M.M., and Masih, R. (1996) Temporal causality and the dynamics of different categories of crime and their socioeconomic determinants: evidence from Australia, Applied Economics, 28, 1093-1104.

Meera, A.K, and Jayakumar, M.D. (1995) Determinants of crime in a developing country: a regression model, Applied Economics, 27, 455-460. 
Melick, M. D. (2003) The relationship between unemployment and crime, The Park Place Economist, 11, 29-36.

Narayan, P., and Smyth, R. (2004) Crime rates, male youth unemployment and real income in Australia: evidence from Granger causality tests, Applied Economics, 36, 2079-2095.

Narayan, P.K. (2005) The savings and investment nexus for China: evidence from cointegration tests, Applied Economics, 37, 1979-1990.

Nikolas, D., Alexandros, G. (2009) The effect of socio-economic determinants on crime rates: an empirical research in the case of Greece with cointegration analysis, International Journal of Economic Sciences and Applied Research, 2, 51-64.

Pesaran, M. H., Shin, Y., and Smith, R. J. (2001) Bounds testing approaches to the analysis of level relationships, The Journal of Applied Econometrics, 16, 289-326.

Phillips, P.C.B. and Perron, P. (1988) Testing for a unit root in time series regression, Biometrika, 75, 335-346.

Sims, C. A. (1980) Macroeconomics and reality, Econometrica, 48, 1-48.

Saridakis, G. (2004) Violent crime in the United States of America: a time-series analysis between 1960-2000, European Journal of Law and Economics, 18, 203-214.

Scorcu, A., and Cellini, R. (1998) Economic activity and crime in the long-run: an empirical investigation on aggregate data from Italy, 1951-1994, International Review of Law and Economics, 18, 279-292.

Shoesmith, G.L. (2010) Four factors that explain both the rise and fall of US crime, 19702003, Applied Economics, 42, 2957-2973.

Soares, R. (2004) Development, crime and punishment: accounting for the international differences in crime rates, Journal of Development Economics, 73, 155-184.

Reilly, B., and Witt, R. (1992) Crime and unemployment in Scotland: an econometric analysis using regional data, Scottish Journal of Political Economy, 39, 213-228. 